${ }^{1}$ Oakley $\mathrm{C}$, Doherty $\mathrm{P}$. Pregnancy in patients after valve replacement. $\mathrm{Br}$ Heart $\mathcal{F} 1976 ; 38: 1140-8$.

2 Sugrue D, Blake S, Troy P, MacDonald D. Antibiotic prophylaxis against infective endocarditis after normal delivery-is it necessary? Br Heart 7 1980;44:499-502.

${ }^{3}$ McLeod AA, Jennings KP, Townsend ER. Near fatal puerperal thrombosis on Björk-Shiley mitral valve prosthesis. Br Heart $\mathcal{F} 1978$;40:934-7.

4 Todd ME, Thompson JH Jr, Bowie ETJ, Owen LA. Changes in blood coagulation during pregnancy. Mayo Clin Proc 1965;40:370-83.

5 Shaper AG, Macintosh DM, Evans CM, Kyobe J. Fibrinolysis and plasminogen levels in pregnancy and the puerperium. Lancet 1965;ii:706-8.

6 Brakman P. The fibrinolytic system in human blood during pregnancy. Am $\mathcal{F}$ Obstet Gynecol 1966;94:14-20.

7 Hall JG, Pauli RM, Wilson KM. Maternal and fetal sequelae and anticoagulation during pregnancy. Am $\mathcal{F}$ Med 1980;68:122-40.

$\checkmark$ Villasanta U. Thromboembolic disease in pregnancy. Am $\mathcal{F}$ Obstet Gynecol $1965 ; 93: 142-60$.

${ }^{9}$ Bennett GG, Oakley CM. Pregnancy in a patient with a mitral-valve prosthesis. Lancet 1968; :616-9.

${ }^{10}$ Chen WWC, Chan CS, Lee PK, Wang RYC, Wong VCW. Pregnancy in patients with prosthetic heart valves: an experience with 45 pregnancies. $Q \mathcal{F}$ Med 1982;203:358-65.

${ }^{11}$ Ibarra-Perez C, Arevalo-Toledo N, Alvarez-De La Cadena, O, NoriegaGuerra $\mathrm{L}$. The course of pregnancy in patients with artificial heart valves. Am $\mathcal{F}$ Med 1976;61:504-12.

12 Anonymous. Anticoagulants and heart valve replacement in pregnancy. $\mathrm{Br}$ Med F 1977;i:1047-8.

13 Edmiston WA, Harrison EC, Duick GF, Parnassus W, Lau FYK. Thromboembolism in mitral porcine valve recipients. $\mathrm{Am} ₹ \mathrm{Cardiol}$ $1978 ; 41: 508-11$.

14 Curcio CA, Commerford PJ, Rose AG, Stevens JE, Barnard MS. Calcification of glutaraldehyde-preserved porcine xenografts in young patients. 7 Thorac Cardiovasc Surg $1981 ; 81: 621-5$.

15 Lutz DJ, Noller KL, Spittell JA, Danielson GK, Fish CR. Pregnancy and its complications following cardiac valve prostheses. Am $\mathcal{f}$ Obstet Gynecol $1978 ; 131: 460-8$.

\section{Epidemiology: a losing cause?}

Mortality statistics have been used for over three centuries to direct health services towards needs and to examine the outcomes of medical intervention-but they are only one measure by which epidemiological data can help monitor the outcome of health service policies. The report of the Royal Commission on the National Health Service stated ${ }^{1}$ that "Without explicit measures of the need of groups of patients for health care, rational decisions on priorities and geographical distribution of resources are impossible. The lack of outcome measures means that judgments of the efficiency of health service delivery rest on insecure foundations." Yet the first report of the Steering Group on Health Services Information, chaired by Mrs Edith Körner," has suggested a "district minimum data set" giving the administrative characteristics of patients passing through hospital but saying nothing about outcome. Hospital clinicians and community physicians will be left without the central information they need for effective management.

At the time of reorganisation of the NHS in 1974 several reviews showed that the information available for planning, management, and monitoring was unsatisfactory both in coverage and quality. ${ }^{3-6}$ The Department of Health and Social Security first tackled community health statistics, ${ }^{7}$ and then began to look more widely at the routine information being collected in the NHS. ${ }^{8}$ Seminars sponsored by the DHSS at the NHS Training and Studies Centre, Harrogate, ${ }^{9} 10$ discussed ways of encouraging hospital clinicians to make use of administrative data. The DHSS kept information as a priority after the 1979 change in government, and the joint DHSS-NHS Information Steering Group was established in February 1980. Its terms of reference were to review and suggest changes in health services information systems. But it $\frac{\text { wo }}{\frac{1}{2}}$ chose to interpret this brief narrowly, concentrating on $\stackrel{\Phi}{\circ}$ information "for the monitoring and control of resource $c$ utilisation."

Indeed, the steering group referred to the paragraph from the royal commission quoted above but rejected its view, $\mathbb{\Phi}_{\mathbb{D}}$ claiming that information about the occurrence of disease or about the health needs of populations was beyond the scope $?$ of its work and that data describing health state or the clinical and social outcomes of the use of health services were "not $\stackrel{\text { क }}{\rightarrow}$ sufficiently developed to allow their introduction" routinely.

Such logic is hard to follow. If the Health Service is to be $\frac{\bar{\sigma}}{\bar{\omega}}$ managed effectively, whether by clinicians themselves, the $\vec{\Phi}$ health authorities, or their officers, epidemiological information should be available describing the extent of health ${ }^{\infty}$ problems and whether the outcome of the service has been $\vec{\circ}$ useful. Information about the process of health care does not $\overrightarrow{\vec{\omega}}$ meet this need, except in the limited instance, for example, $\stackrel{\circ}{\circ}$ of describing the number of operations performed each year 3 for a given population.

How did the steering group make this decision? Of its 17 members, five represented community medicine-one $\mathcal{E}^{-}$ academic, one civil servant, and three working in the NHSbut no one at district level nor any epidemiologist from the $\vec{\sigma}$ Office of Population Censuses and Surveys. While the steering group may believe that the current information on need and $\mathrm{O}$ outcome is inadequate, so indeed is the administrative $N_{\infty}$ information, and the committee has put considerable effort 3 into improving that. Why were epidemiological measures excluded from this effort-at a time when many members of $\overrightarrow{0}$ district health authorities and community health councils are $\mathbb{E}^{\infty}$ becoming better informed about health care needs and the policy options that may lead to improvements in health ?11 120 The regional and district management teams need to learn each other's perspectives, and without epidemiological information clinicians and community physicians will be less $\frac{\mathbb{Q}}{\square}$ able to inform their non-medical colleagues. Further, the $\overrightarrow{\vec{A}}$ emphasis on process rather than diagnostic information 3 justifies administrators' expectations that the line management $\bar{F}$ of information services should be within the administrator's? hierarchy, leaving medical officers without adequate support, particularly at district level.

The cost of implementing the Körner steering group's recommendations will be high: the expense and effort of getting "minimum data sets" in each district and region willo leave precious little for developing epidemiological information. Indeed, the North East Thames region has recently abandoned cancer registration while pressing ahead with the steeringo group's improvements in process information.

In a timely statement just published the presidents of the three Royal Colleges of Physicians and their Faculties of ${ }^{N}$ Community Medicine and Occupational Medicine, and the $\mathrm{W}$ Royal College of Psychiatrists, have come together to emphasise? the importance of epidemiology in medical practice. ${ }^{13}$ They recommend that training posts and programmes should bee established jointly between clinical specialties and academic departments of community medicine, with suitable accreditation for joint career posts, and they encourage the universities and the NHS departments of community medicine to give adequate $\stackrel{\mathbb{Q}}{\stackrel{\mathbb{P}}{2}}$ funding for these developments.

These are practical proposals, and could indeed be extended. All medical students in Britain now have some experience in epidemiology, though the understanding may be extinguished during their years of hospital residency. Courses in epidemiology and management should be available as post- 
graduate training for all doctors. Clinicians will increasingly recognise that they have interests in common with community physicians to improve the health of the district in their specialty through prevention, and to sustain their patients in the community after hospital care, with the general practitioner.

The Chief Medical Officer designate for England and Wales, Professor Donald Acheson, has been at the forefront of raising interest in clinical epidemiology. ${ }^{14} \mathrm{We}$ can expect him to support the royal colleges' initiative; but can he also move the Körner steering group along more fruitful paths?

Senior Lecturer in Community Medicine,

MARK MCCARTHY

University College London,

London WC1E 6JJ

${ }^{1}$ Royal Commission on the National Health Service. Report. London: HMSO, 1979: paragraph 21.57. (Cmnd 7615.) (Merrison report.)

${ }^{2}$ Steering Group on Health Services Information. First report to the Secretary of State. London: HMSO, 1982. (Körner report.)

${ }^{3}$ Bispham $\mathrm{K}$, Thorne $\mathrm{S}$, Holland WW. Information for area health planning. In: McLachlan G, ed. Challenges for change: essays on the next decade in the National Health Service. London: Oxford University Press, $1971: 235-61$.

+ Doll R. Monitoring the National Health Service. Proceedings of the Royal Society of Medicine 1973;66:729-40.

${ }^{5}$ Alderson MR. Central government routine health statistics. London: Heinemann Educational, 1974. (Reviews of United Kingdom statistical sources. Vol 2.)

${ }^{6}$ Acheson RM, Hall DJ, editors. Seminars in community medicine. Vol 2. Health information, planning and monitoring. London: Oxford University Press, 1977.

Department of Health and Social Security. Review of community health services statistics: second and final report of the working group. London: HMSO, 1978. (HN(78)38.)

* Department of Health and Social Security. Information requirements of the health services. London: HMSO, 1979. (HN(79)21.)

${ }^{9}$ Anonymous. Hospital costing and the clinician. London: Department of Health and Social Security, 1978. (Harrogate seminar reports, 1.)

${ }^{10}$ Anonymous. Waiting for hospital treatment. London: Department of Health and Social Security, 1980. (Harrogate seminar reports, 2.)

11 Kennedy I. The unmasking of medicine. St Albans: Granada Publishing, 1983.

${ }^{12}$ McCarthy M. Epidemiology and policies for health planning. London: King's Fund, 1982.

${ }^{13}$ Smith A, Black D, Thomson TJ, Girdwood RH, Taylor PJ, Rawnsley K. Importance of epidemiology. Lancet 1983;i:928.

1 Acheson ED. Clinical practice and community medicine. $\mathrm{Br}$ Med $\mathrm{f}$ 1979 ;ii:880-1.

\section{Update on insulin dependent diabetes}

The pace of research into the aetiology and pathogenesis of insulin dependent (type I) diabetes has increased over the past 10 years and this has been reflected in a series of international symposia and workshops. The most recent was the fourth international workshop on "The immunology of insulin dependent diabetes mellitus," held in London in April. The need for progress in our understanding of the aetiology of this form of diabetes was emphasised at the outset by J Nerup (Denmark), who pointed to the failure of modern insulin treatment appreciably to reduce long term morbidity.

The characteristic presentation of insulin dependent diabetes has fostered the assumption that most cases result from an acute pathological event occurring just before the onset of symptoms. Perhaps the most important change in our concept of the disorder is the realisation that, in some cases at least, damage to the islet cells probably occurs over several years before the severe metabolic breakdown that results in symptoms. This may occur even in those patients who have had an acute infective episode before the clinical onset of diabetes.

W Gepts (Belgium) reviewed the histological findings and emphasised that these may vary from case to case. Cellular infiltration of the islet cells is only one of the features seen; other changes include pseudoatrophy, which suggests that damage to the islet cells occurs over a long time. Studies of diabetes induced by viruses and chemical agents-for example, cytomegalovirus, reovirus, streptozotocin (A L Notkins, United States; A D Toniolo, Italy)-have suggested that sequential exposure to such agents may lead to cumulative damage to the $\beta$ cells of the pancreas. D C Gajdusek (United States) pointed out that some viruses may remain in the tissues for many years before they exert a cytopathic effect, the target tissue often being highly specific for a particular virus. F Ginsberg-Fellner (United States) reported the development of diabetes in 18 people out of 600 who had suffered from congenital rubella. In some cases the diabetes had presented as late as 14 years of age.

Further evidence comes from advances in our knowledge of the genetics of insulin dependent diabetes with the possibility through HLA typing of ascertaining certain highly susceptible subjects. This has been done in the Barts-Windsor family study, and some of the findings from this study were reported by $\mathrm{K}$ Spencer and P Pozzilli (Britain). Complement fixing islet cell antibodies, particularly in the healthy haploidentical siblings of probands, were detectable for as long as three years before the clinical onset of diabetes. Moreover, there was preliminary evidence in some of these subjects of an increased number of activated $T$ cells and of a fall in $T$ suppressorcytotoxic cells in the peripheral blood.

It is possible that the destruction of $\beta$ cells is mediated via immunological processes irrespective of the environmental trigger. This theory was raised several years ago and is supported by the presence of islet cell antibodies in the serum of most patients at the time of clinical presentation. G F Bottazzo (Britain) described further findings such as the presence of IgG at the surface of and within islet cells, with IgG bearing lymphocytes and activated $T$ lymphocytes infiltrating the islets in patchy fashion. These findings are consistent with the concept that destruction of $\beta$ cells may result from the synergistic action of both humoral and cell mediated attack. The potential pathological effects of antibody were shown by experiments reported by A Lernmark (Denmark), in which insulin release by isolated islet cells after a glucose stimulus was appreciably reduced when the cells were perfused with IgG fractions of sera from diabetics.

Review of the genetic aspects of insulin dependent diabetes showed general agreement that more than one HLA linked susceptibility gene is implicated. Three high risk haplotypes are known, two including DR3 and one DR4. We do not know where exactly along the chromosome the relevant genes are, but rapidly developing knowledge of the closely linked polymorphisms in the DR region should bring us closer to the loci which actually determine who is susceptible to diabetes.

Looking to the future, we should like to be able to detect susceptible people and protect them from the environmental trigger factors or to block the processes that lead to destruction of $\beta$ cells. Only an optimist would claim that we shall be able to achieve this in the near future, but current research isat the very least-marking out the directions in which further information is urgently sought.

Professor of Medicine,

J C WOODROW

Department of Medicine,

University of Liverpool,

Liverpool L69 3BX 